\title{
Article \\ Decay Process of Serpentinite: The Case of the San Giovanni Baptistery (Florence, Italy) Pavement
}

\author{
Alba Patrizia Santo ${ }^{1, *} \mathbb{C}$, Beatrice Agostini ${ }^{2}$, Carlo Alberto Garzonio ${ }^{1}$, Elena Pecchioni ${ }^{1}$ and Teresa Salvatici ${ }^{1}(\mathbb{C}$ \\ 1 Department of Earth Sciences, University of Florence, 50121 Firenze, Italy; \\ carloalberto.garzonio@unifi.it (C.A.G.); elena.pecchioni@unifi.it (E.P.); Teresa.salvatici@unifi.it (T.S.) \\ 2 Opera di Santa Maria del Fiore, 50122 Firenze, Italy; b.agostini@duomo.firenze.it \\ * Correspondence: alba.santo@unifi.it
}

check for

updates

Citation: Santo, A.P.; Agostini, B.;

Garzonio, C.A.; Pecchioni, E.;

Salvatici, T. Decay Process of

Serpentinite: The Case of the San

Giovanni Baptistery (Florence, Italy)

Pavement. Appl. Sci. 2022, 12, 861.

https://doi.org/10.3390/

app12020861

Academic Editors: Lola Pereira and

Asterios Bakolas

Received: 27 November 2021

Accepted: 11 January 2022

Published: 14 January 2022

Publisher's Note: MDPI stays neutral with regard to jurisdictional claims in published maps and institutional affiliations.

Copyright: () 2022 by the authors. Licensee MDPI, Basel, Switzerland. This article is an open access article distributed under the terms and conditions of the Creative Commons Attribution (CC BY) license (https:// creativecommons.org/licenses/by/ $4.0 /)$.

\begin{abstract}
Serpentinite is a low-grade metamorphic rock derived from the transformation of ultramafic rocks. Mainly because of its aesthetic characteristics it has been widely used as a building and ornamental stone. "Verde di Prato" is the most common local name used in Tuscany to refer to this type of rock, historically quarried in this area and used for many centuries in a large number of monuments of this region. In this paper, we report the results of a study carried out on the serpentinite from the pavement of the Florence baptistery, to properly characterize it from a physical point of view, describe the rock conservation state, and understand the phenomena responsible for its decay. The studied rock displays numerous forms of decay including fractures, loss of material, erosion, discolouration and efflorescence. X-ray diffractometer analyses of the efflorescence revealed the presence of numerous salts whose formation can be imputed to multiple, possibly concomitant, causes such as the high relative humidity and the variation of inside temperature, the presence of concrete and/or cementitious mortars in the subsoil, atmospheric pollution and the burial ground existing close the baptistery.
\end{abstract}

Keywords: serpentinite; San Giovanni baptistery; Florence; decay; efflorescence

\section{Introduction}

Natural stones, due to their mechanical and aesthetical characteristics and versatility, have been used as building and monument materials in antiquity, starting with the Egyptians about 4700 BC [1].

According to the general belief, rocks are durable materials; however, their durability is not infinite, and many factors may contribute to reducing it; indeed, all rocks undergo gradual or sudden weathering and decay, depending on the extrinsic environment characteristics and intrinsic stone properties. The weathering and deterioration of historical buildings, as well as that of many monuments or sculptures made of natural stones, is a problem that has been known since antiquity. The causes of deterioration can be multiple; when a stone is removed from its natural place of origin is not preserved from deterioration, but it suffers due to several factors related to the production (e.g., quarrying and stockpiling), construction, use, and the characteristics of the new environment, which all come into play, increasing the chances of decay. The parameters which characterize the new place (e.g., the building, the atmospheric conditions, the air pollution, etc.) interact in a complex way with the stone surface. They are not limited to outdoor conditions. Indeed, many problems are common to both outdoor and indoor environments, although the complexity level may change and the indoor conditions can be, in principle, monitored [2]. The use of natural stone in buildings requires that the stone type displays the right suitability for the intended purpose. Otherwise, its deterioration might occur even after short periods. However, in the past, only locally available resources were often used due to the difficulty and cost of transporting stones from a distant source and to the low knowledge on which 
rocks were best suited to the different use. As a consequence, entire towns were built using just a few types of rocks, thus establishing a strong relationship between the local community, the tradition, and the landscape [3]. This happened also in the city of Florence which was mainly constructed using the sandstones outcropping around the town; other stones (such as marble, limestone, and serpentinite) were partly selected because of the availability and/or the aesthetic appearance. This is the case of the serpentinite which, due to its compositional and physical-mechanical characteristics, displays moderate weathering resistance. Two-colour (white and green) decorations are, for instance, characteristic of Tuscan Romanesque; significant examples are to be found in Pisa, Pistoia, Lucca, and Florence. In particular, the so-called "green marble" was used in Florence for the revetment of important monuments such as the baptistery, the cathedral, and the Santa Croce church. In the case of the San Giovanni baptistery, serpentinite was also used inside on the walls and floor where inlays of green (serpentinite), white (marble), and red (limestone) stones form an oriental motif. In this paper, we report the results of a study performed on the serpentinite from the pavement of Florence baptistery. The baptistery, dedicated to San Giovanni, the patron saint of Florence, is one of the oldest and most important buildings of the city and world; the decay of its floor has never been studied and therefore it was necessary to fill this gap to verify the state of conservation, understand the processes responsible for its decay and decide the more appropriate intervention(s).

\section{The San Giovanni Baptistery}

The baptistery of Florence (Figure 1) is part of the great monumental complex of Santa Maria del Fiore which comprehends the namesake cathedral, the baptistery, and the Giotto Bell Tower; it stands between Piazza del Duomo and Piazza di San Giovanni, in the historic centre of Florence which has been a UNESCO World Heritage Site since 1982. A special, almost magical, relationship exists between the baptistery and the Florentine people; it was intended for the liturgical function of baptism, a rite which large crowds attended, but following several authors e.g., [4] in the 10-11th centuries it acted also as Florence's cathedral. Numerous personalities such as the poet Dante Alighieri and members of the Medici family were baptized in this baptistery. The age of the baptistery is still so debated and controversial that Toker [5] defined it as "among the most enigmatic buildings in Europe"; it is an early Christian or a medieval building? did the monument originate as a pagan temple or as a church? In the opinion of the architect Piero Degli Innocenti [6], who has spent a long time studying the matter, the present baptistery was built as a memorial to the defeat, in A.D. 406, of Radagaiso, a Gothic king who had invaded Roman Italy, by Stilicho, a military commander in the Roman army; later (1059), the building was consecrated to Christian worship by Pope Nicholas II [4,7].

Archaeological campaigns (1895-1915) carried out below the Santa Maria del Fiore cathedral, the baptistery and the surrounding areas, have played an important role in the studies related to the origin of the baptistery; they revealed the remains of ancient Florentine Domus, possibly destroyed before the construction of the new building [4,8], providing a very useful and substantial review of all previous investigations and hypotheses about the origin of the monument, and attributed the original construction to the early Middle Ages. New excavations were made during the 20th century [7] in correspondence of the square (Piazza del Duomo) between Santa Maria del Fiore cathedral and the baptistery; in particular, the 1971-1972 excavations revealed the concrete foundations of Roman walls, overlapped by more recent walls made of modern concrete, and by a burial ground, possibly dating back to the twelfth century [7].

In addition, two furnaces for lime were found and the coal contained in them was dated to the 11th century [7]. Unfortunately, all the available documents are inconclusive, not sufficient to resolve the doubts about the origin of this important monument, and, therefore, the age question periodically resurfaces. A radiocarbon dating of chestnut wood, obtained by Bernabei et al. [9] while studying the timber structure of the dome, gave an age corresponding to the 11th-12th centuries. 


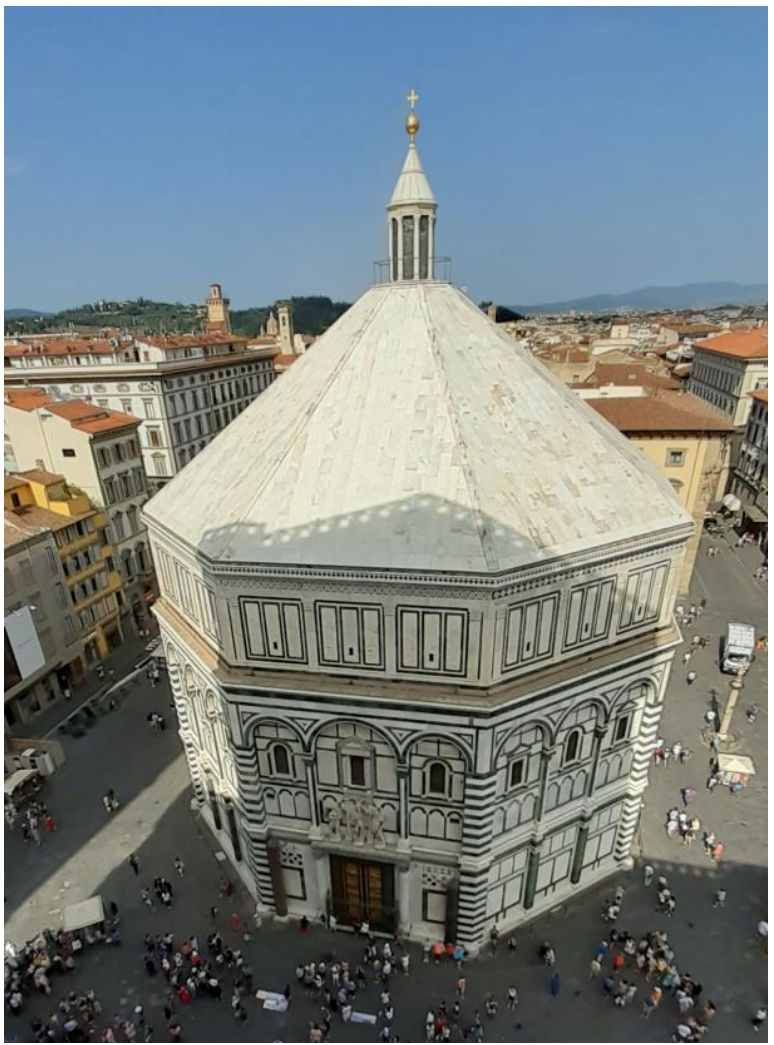

Figure 1. The Baptistery of San Giovanni as seen from the terrace of the Santa Maria del Fiore cathedral.

The San Giovanni baptistery has an octagonal plant, the common shape displayed by several baptisteries since early Christian times. The external walls are characterised by the prevalent two-colour (white and green) revetment, typical of Florentine Romanesque architecture, obtained through the use of marbles and serpentinites. Marble slabs are of both Italian (Carrara and Lasa varieties) and Greek (Pentelico and Imetto varieties) provenience; this latter possibly correspond to reused spolia-marble from Fiesole (the Roman Faesulae) monuments [10]. In the interior of the baptistery, the walls of the lower part are covered by marbles and serpentinites; each side displays granite and marble columns and pilasters; the style of cladding is reminiscent of the Byzantine one [8]. The upper part has the galleries reserved, in the past, for women (matroneum). An inner octagonal dome, resting on the perimetral walls, surmounts the baptistery, covered on its outside by a pyramid shaped masonry. Unlike the walls, characterized by two-colour decorations (Figure 2), for the baptistery pavement, believed dating back to the beginning of the 13th century [11], a polychrome revetment, white, red, and green, was utilized. The baptistery has three magnificent, gilded bronze doors on the North, East, and South sides, the west side houses the so-called "scarsella", the quadrangular apse. Galleries, dome, and apse are decorated with magnificent and precious mosaics depicting various sacred images.

\section{The Baptistery Pavement}

The polygonal floor of the baptistery is mainly covered with white (marble), green (serpentinite) and red (limestone) inlays, forming a geometrically and oriental patterned carpet. Two areas are at the present made of cocciopesto; they correspond to the area in front of the apse and to the octagonal central area where the baptismal font was located in the past; at present, the font, much smaller than the ancient one, stands between the east and south entrances (Figure 2). Furthermore, in a few small areas, a different red rock (andesitic porphyry) was used.

Over the years, the floor has undergone numerous transformations, about which unfortunately we have little information [7]. According to some historical papers [7,12], 
important transformations were carried out by Bernardo Buontalenti in 1577. Recently, in the first half of the 20th century, an important structural intervention was necessary to consolidate the entire floor; some supporting structures, possibly metallic, and a reinforced modern concrete base were inserted during these works, as revealed by recent geo-radar measurements [13].

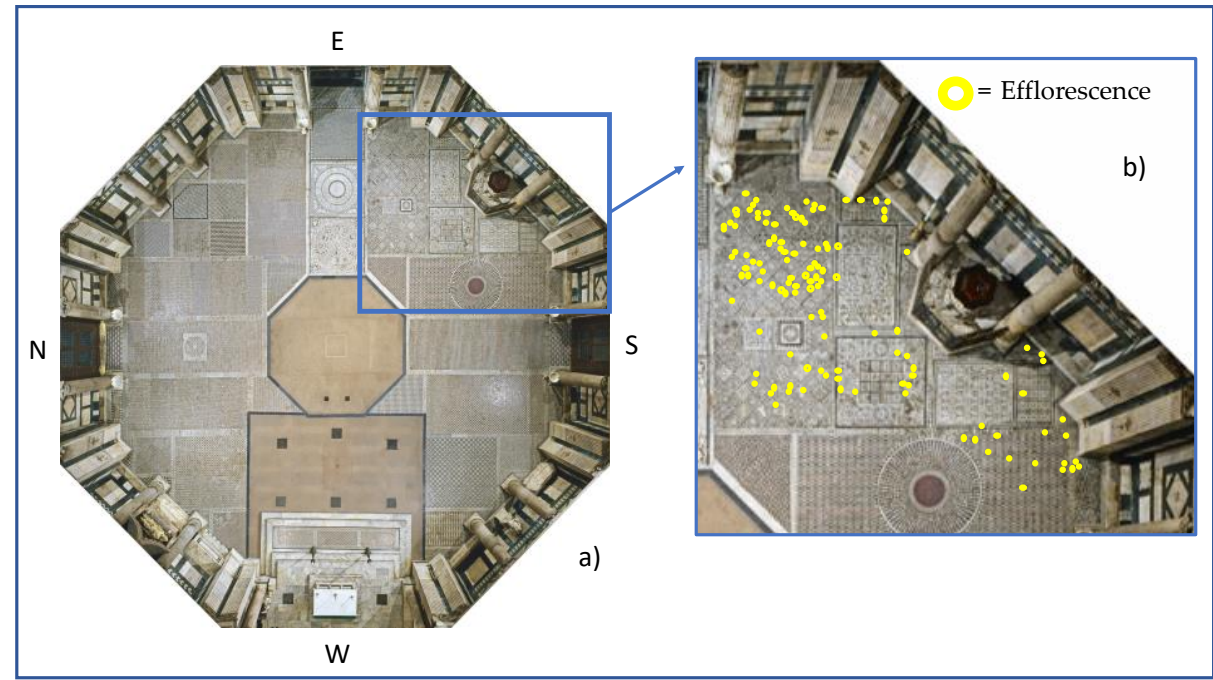

Figure 2. (a) The pavement of the San Giovanni baptistery [14]; (b) The efflorescence map of the studied pavement area.

The pavement can be metaphorically compared to a carpet showing a complex pattern made of geometric, fantasy plant and animal motifs. It does not show a single design, but rather various sections that possibly correspond to different periods of its history [8]. In the predominantly two-colour part (e.g., Figure 3a), supposed to be the oldest [8], the opus interassile technique, in which slabs of a lithotype was dug and filled with coloured shaped stones, was used. The other portions (e.g., Figure 3b) were realised through the three-colour opus sectile technique in which stone tiles, of various shapes and equal thickness, were placed side by side on a bed of binder mixed with mortar and pozzolana [8] and form geometric patterns. Very remarkable is the Zodiac (Figure 3c), which possibly [12], was used as a gnomon to identify the summer solstice sign. In the following sections, we will focus on the serpentinite inlays.

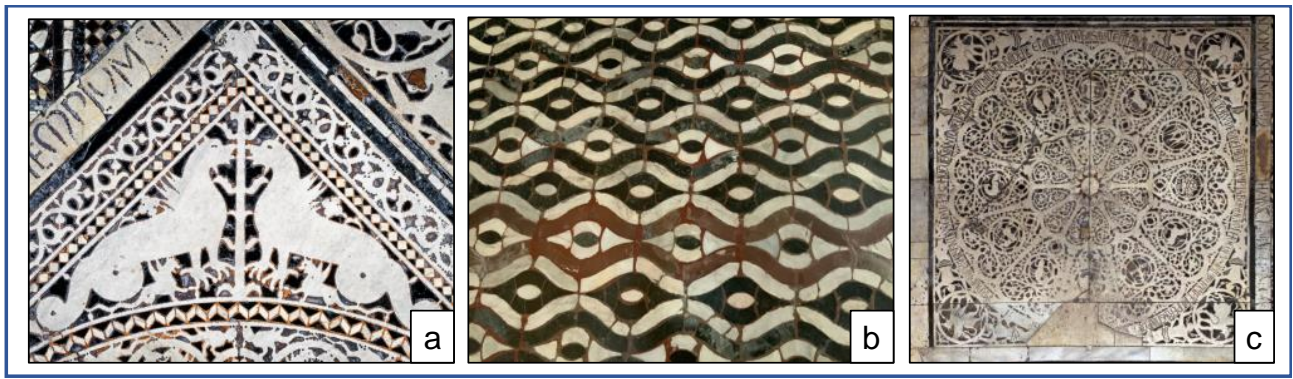

Figure 3. The pavement of the San Giovanni baptistery. (a) Detail showing fantastic animals facing one another (Archive of the Opera di Santa Maria del Fiore); (b) Detail of the three-colours geometric motif; (c) The zodiac showing in its centre the image of a flaming anthropomorphic Sun; the latter is surrounded by the signs of the constellations, inserted in a cosmic circle which in turn is inscribed in a square. 


\section{Serpentinites}

Serpentinites are metamorphic rocks derived by hydration processes, at low-intermediate temperatures $\left(100-700^{\circ} \mathrm{C}\right)$, of olivine-rich ultramafic rocks. The pre-existing anhydrous minerals, olivine, pyroxene, and other $\mathrm{Mg}$-rich silicates and carbonates are mainly replaced by the serpentinite-group minerals and, in a lower amount, by other minerals such as magnetite, brucite, talc, calcite and magnesite. The most common serpentine-group minerals (approximate formula $\mathrm{Mg}_{3} \mathrm{Si}_{2} \mathrm{O}_{5}(\mathrm{OH})_{4}$ ) are three different polymorphs, i.e., lizardite, which displays a flat crystal structure, chrysotile, characterised by cylindrical fibres even several centimetres in length, and antigorite, which exhibits an interlocking texture. The resulting fine-grained, dark green to black in colour, rock displays lower density than the protolith, having relatively high porosity and absorption coefficient; it is commonly crossed by veins of variable composition and has a high tendency to shear and failure. The serpentinization process may obliterate, totally or in part, the primary mineralogy of rocks; in any case, during the hydration process, the volume of the rock expands, the original structure is modified with consequent weakness of the rock mechanical properties. The serpentinite behaviour can be influenced also by carbonation, a very common process that consists of precipitation of carbonates in the shears and fractures of serpentinite; during this process, the serpentine-group minerals can be transformed into carbonates depending on the fluid composition and availability of magnesium and calcium in the original rock [15].

Serpentinite displays moderate weathering resistance and a fragile behaviour; despite these characteristics, this rock has been used throughout the history of civilization for ornamental and building purposes and it is found in historical and modern buildings. Egypt, where this rock was used since antiquity, is characterized by widespread occurrences of serpentinites in the Eastern Desert; however, the serpentinites most widely used for ornamental purposes possibly come from India but also from China, USA, Spain, Italy [15]. Serpentinites used in Italy were coming prevalently from the Northern Apennine until the quarries had closed down and other green rocks (e.g., Verde Alpi), showing different compositional and mechanical characteristics, were used [16].

\section{Materials and Methods}

The baptistery pavement, although numerous restorations, interventions and replacements of inlays have been made over the years, displays many forms of decay; the different stone inlays are characterised by discolourations, fractures, loss of material, differential erosion, lacunae (e.g., Figure 4).

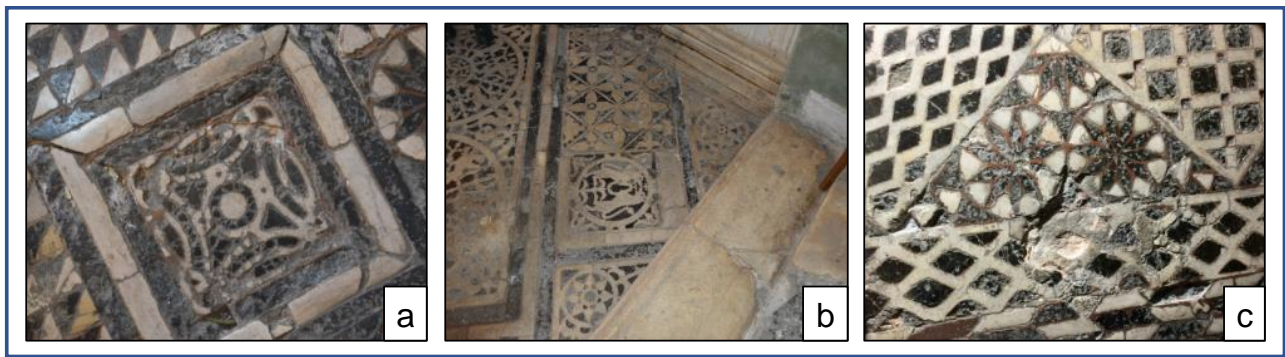

Figure 4. Fracture $(\mathbf{a}, \mathbf{b})$, loss of material $(\mathbf{a}-\mathbf{c})$, discolouration $(\mathbf{b})$, differential erosion $(\mathbf{a}, \mathbf{c})$, lacunae (c).

Furthermore, on the serpentinite surface, white efflorescence is visible (Figure 5a,b) unlike on the marble and limestone. A careful observation of the entire pavement showed that this phenomenon is particularly evident in the SE sector. Consequently, our study was mainly aimed at the serpentinites of this area (Figure 2) located between the southern and eastern doors, close to the baptismal font; here the efflorescence is also abundant on the wall (Figure 5c). 


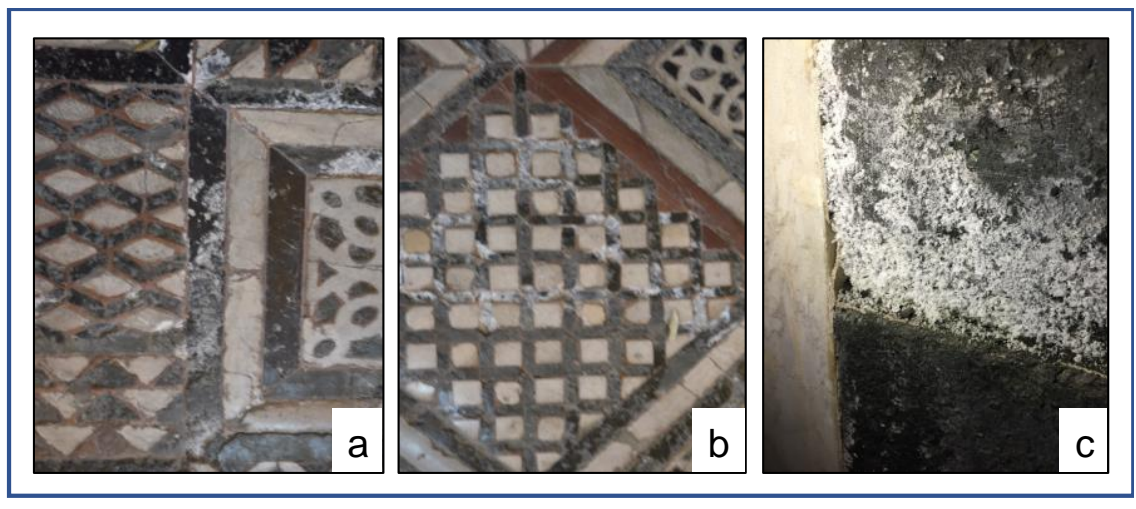

Figure 5. Details of the efflorescence on the serpentinite floor $(\mathbf{a}, \mathbf{b})$ and wall (c).

The efflorescence mapping of the studied surface area was obtained in a manual way through a detailed visual inspection and photographic documentation. Some physical characteristics such as capillary water absorption, open porosity, apparent density and imbibition coefficient were obtained on a few samples of serpentinite. The capillarity water absorption test was performed according to UNI-EN 1925 [17]; open porosity, apparent density and imbibition coefficient results were obtained according to UNI EN 13755 [18]. The capillarity water absorption tests were carried out on two serpentinite inlays from the baptistery floor [19], on both sides, the upper, showing evidence of decay (AL) and the lower, which appears unaltered (UN). To obtain the open porosity, apparent density, and imbibition coefficient data it was necessary to cut the samples removing the altered surface. For comparison, we tested also a few rock samples collected at the Monte Ferrato and Impruneta areas (Tuscany) considered to be the ancient supply quarries of the baptistery serpentinites [19].

For compositional analysis, we collected superficial material from the marble, limestone and serpentinite inlays; the surface was gently scraped in several areas with a spatula and the obtained powders were analysed. For comparison, we also collected one sample from a wall. The sample compositions were obtained by using an X-ray diffractometer (XRD) and Fourier transform infrared spectroscopy (FT-IR); XRD analysis was conducted using a PANAlytical (Malvern Panalytical, Almelo, NL) diffractometer with CuK $\alpha 1$ radiation $\left(\lambda=1.545 \mathrm{~A}^{\circ}\right)$ and a graphite monochromator, operating at $40 \mathrm{kV}, 20 \mathrm{~mA}$, investigated range $2 \theta=5-70^{\circ}$, software $X^{\prime}$ PertPRO and High Score for data acquisition and data interpretation of the mineralogical composition; the detection limit is $4 \%$. FT-IR analyses were carried out through ATR mode with a Spectrum 100 FTIR spectrometer (Perkin-Elmer Inc., Norwalk, CT, USA) equipped with a Universal ATR accessory. The acquisition was performed at room temperature, in the spectral range between 4000 and $350 \mathrm{~cm}^{-1}$, repeating 4 scans with a resolution of $4 \mathrm{~cm}^{-1}$. The data were acquired and processed using the Spectrum 100 software.

During the investigation campaign, environmental (superficial and air temperature and humidity) values, inside the baptistery, were also obtained through a resistive, nondestructive, method; the analyses were carried out with the Protimeter Moisture Measurement System2 (Protimeter MMS2, Taunton, UK), which measures the variation of the electrical resistance of a material as a function of its water content. The Protimeter MMS2 measures the "Wood Moisture Equivalent" (\%WME) in non-conductive solid materials; the detection limit is $<7.8 \% \mathrm{WME}$. The scale to determine the level of moisture content is the following:

$7.8>\% W M E<17$ "green" (dry)

$17>\% W M E<20$ "yellow" (risk)

$>20 \%$ WME "red" (wet)

Furthermore, to obtain information on the materials present under the floor, a small core, up to a depth of $25 \mathrm{~cm}$, was carried out in an area where the stone covering was 
already missing; in the core sample we distinguished four different layers which were analysed by XRD.

\section{Results}

Figure 2 shows the baptistery pavement and the studied sector with reported the simplified map of the efflorescence; the composition of the collected samples from the serpentinite surface and the composition of the different portions of the core are reported in Tables 1-3. Table 4 lists the values of the measured physical parameters.

Table 1. Composition of the serpentinite efflorescence obtained by XRD analyses.

\begin{tabular}{ccccccccc}
\hline Sample & Calcite & Quartz & Plagioclase & Lizardite & Trona & Thenardite & Niter & Darapsikite Gypsum \\
\hline EF 1 & $X$ & $X$ & - & $X X$ & - & $X$ & - & - \\
\hline EF 2 & - & - & - & $X$ & - & $X$ & - & - \\
\hline EF 3 & $X X$ & tr & - & $X X$ & $X$ & $X$ & - & - \\
\hline EF 4 & - & - & - & $X X$ & - & - & - & - \\
\hline EF 5 & $X X$ & $X$ & tr & tr & - & - & - & - \\
\hline EF 6 & - & $X$ & - & $X$ & - & - & - & - \\
\hline EF 7 & $X$ & - & - & $X$ & $X$ & - & $X$ & tr \\
\hline EF 8 & tr & - & tr & $X X$ & $X$ & - & - & - \\
\hline EF 9 & - & - & $\operatorname{tr}$ & $X$ & $X$ & - & - & - \\
\hline EF 10 & - & - & - & $X X$ & - & - & - & - \\
\hline EF 11 & $X$ & $X$ & tr & $X$ & $X$ & $X$ & - & - \\
\hline
\end{tabular}

$\mathrm{XX}$ : high content; $\mathrm{X}$ : low content; tr: in trace content.

Table 2. Composition of the different portions of the core obtained by XRD analyses.

\begin{tabular}{cccccccccccc}
\hline Sample & Calcite & Dolomite & Quartz & Plagioclase & K-Feldspar & Mica & Chlorite & Lizardite & Hematite & Gypsum & Ettringite \\
\hline BATP1-1 & $X X$ & - & $X$ & - & - & $\operatorname{tr}$ & - & $\operatorname{tr}$ & - & $X$ & tr \\
\hline BATP1-2 & $X X$ & - & $X X$ & $X$ & $X$ & - & - & - & $X$ & - & $X$ \\
\hline BATP1-3 & $X X$ & - & $X X$ & $\operatorname{tr}$ & - & - & $\operatorname{tr}$ & - & $\operatorname{tr}$ & - & - \\
\hline BATP1-4 & $X X X$ & $\operatorname{tr}$ & - & - & - & - & - & - & - & - & - \\
\hline
\end{tabular}

$\mathrm{XXX}$ : very high content; $\mathrm{XX}$ : high content; $\mathrm{X}$ : low content; tr: in trace content.

Table 3. Composition of efflorescence obtained by FT-IR analyses.

\begin{tabular}{clllcc}
\hline EF 1 & Calcite & Quartz & Lizardite & Thenardite & - \\
\hline EF 3 & Calcite & Quartz & Lizardite & Trona & - \\
\hline EF 5 & Calcite & Quartz & - & - & - \\
\hline EF 7 & Calcite & Quartz & Lizardite & Trona & Niter \\
\hline EF 8 & Calcite & Silicate & Lizardite & Trona & - \\
\hline EF 9 & Calcite & Silicate & Lizardite & Trona & - \\
\hline EF 10 & Calcite & Silicate & Lizardite & - & - \\
\hline EF 11 & Calcite & Silicate & Lizardite & trona & - \\
\hline
\end{tabular}


Table 4. Results of physical measurements (mean values).

\begin{tabular}{ccccc}
\hline Sample & $\begin{array}{c}\text { Capillary Water } \\
\text { Absorption } \\
\left(\mathbf{g} / \mathbf{m}^{2} \sqrt{ } \mathbf{s e c}\right)\end{array}$ & $\begin{array}{c}\text { Open } \\
\text { Porosity } \\
\mathbf{( \% )}\end{array}$ & $\begin{array}{c}\text { Apparent } \\
\text { Density (g/cm }\end{array}$ & $\begin{array}{c}\text { Imbibition } \\
\text { Coefficient (\%) }\end{array}$ \\
\hline BAT1 (AL) & 5.44 & 7.68 & 2.52 & 3.15 \\
\hline BAT1 (UN) & 3.18 & 7.14 & 2.51 & 2.92 \\
\hline Monte Ferrato (UN) & 3.46 & 5.59 & 2.55 & 2.24 \\
\hline Impruneta (UN) & 3.08 & 8.07 & 2.49 & 3.34 \\
\hline
\end{tabular}

\subsection{XRD Analyses}

The XRD (Table 1 and Figure 6) analyses of the efflorescence show the presence of salts such as trona $\left[\left(\mathrm{Na}_{3}\left(\mathrm{CO}_{3}\right)\left(\mathrm{HCO}_{3}\right) 2\left(\mathrm{H}_{2} \mathrm{O}\right)\right]\right.$ and / or thenardite $\left(\mathrm{Na}_{2} \mathrm{SO}_{4}\right)$. The sample EF 6 contains a very small quantity of gypsum $\left[\left(\mathrm{CaSO}_{4} \cdot 2\left(\mathrm{H}_{2} \mathrm{O}\right)\right]\right.$. The XRD analyses also revealed the presence of lizardite, coming from the underlying serpentinite, calcite, quartz and feldspar coming from the mortar holding the green tiles together, and from the surrounding tiles. The efflorescence is not visible on the surface of the other rocks used on the floor; analyses were made also on powders scraped from the marble and limestone, but we found only calcite and gypsum on the marble, calcite, quartz, and gypsum on the red limestone. The EF 7 sample was collected from the SE serpentinite wall. In addition to trona, in this sample also niter $\left(\mathrm{KNO}_{3}\right)$ and darapskite $\left.\left[\mathrm{Na}_{3}\left(\mathrm{NO}_{3}\right)\left(\mathrm{SO}_{4}\right) \cdot \mathrm{H}_{2} \mathrm{O}\right)\right]$ were detected.

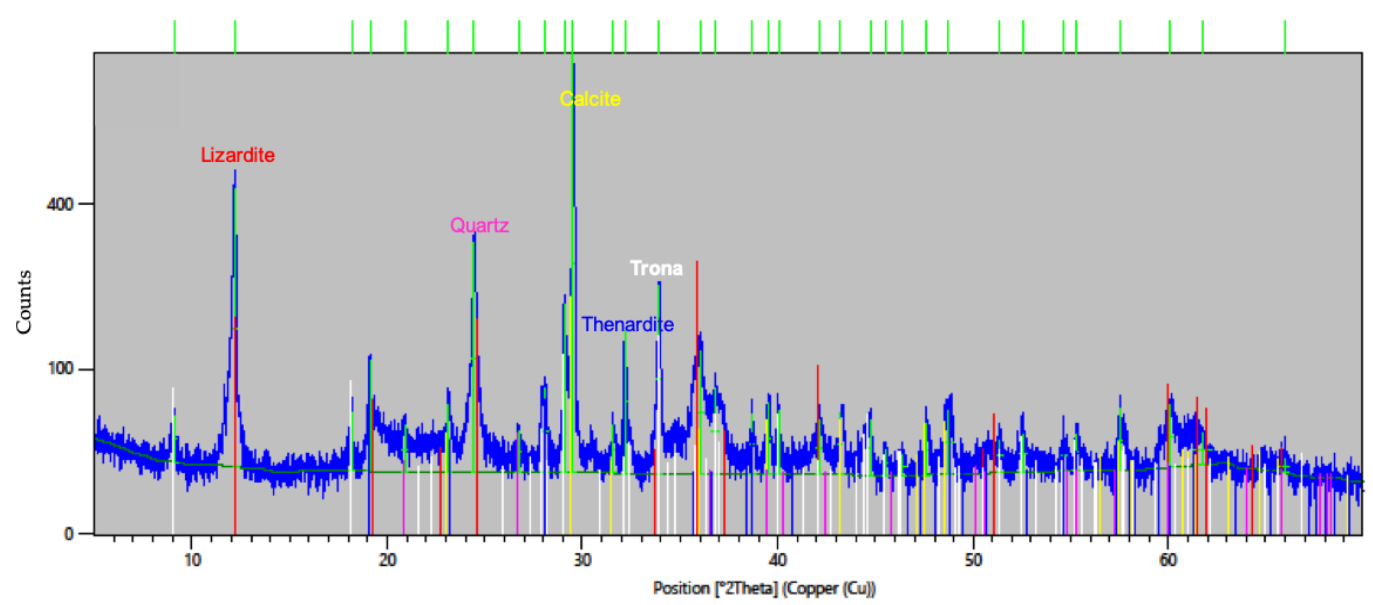

Figure 6. Representative X-ray diffraction pattern (sample EF 3). The different identified compounds are reported in correspondence with the main peaks.

As regards the core composition, it was possible to distinguish four different layers (Table 2) which correspond, from the top to the bottom, to the serpentinite of the pavement mixed with the other rocks of the floor (BAPT1-1), mortar containing fragments of bricks and marble (BAPT1-2), mortar including brick fragments (BAPT1-3), and fragments of marble inside the mortar (BAPT1-4). At the base of these layers, very fine-grained material was used as a filler.

\subsection{FT-IR Analyses}

Infrared spectra of the efflorescence collected from the pavement (Table 3) exhibit the characteristic absorption peaks of calcite (peaks at 1420, 874, and $712 \mathrm{~cm}^{-1}$ ), quartz and other silicates, such as plagioclase (peaks in the range $1100-1000 \mathrm{~cm}^{-1}$ ), and lizardite (peaks at 3690, 3639 and $995 \mathrm{~cm}^{-1}$ ). The results are in good agreement with the XRD data. In almost all the samples, the characteristic peaks of trona, centred at 3460, 1688, 1466 and $843 \mathrm{~cm}^{-1}$ can be observed. In the sample EF 1 the peak of thenardite $\left(1250 \mathrm{~cm}^{-1}\right)$ 
is observed while the sample EF 7 displays the characteristic peaks (at 1377, $1444 \mathrm{~cm}^{-1}$ ) of niter.

\subsection{Physical Characteristics}

The baptistery pavement inlays show a significant difference in the capillarity water absorption values obtained on the upper and lower sides; the altered side displays a higher value compared to those of the lower side and the other studied serpentinite rocks.

Regarding the other physical parameters, all the unaltered samples display comparable values of apparent density and imbibition coefficient; the open porosity of the floor inlay is more similar to the sample coming from the Impruneta quarry, therefore suggesting this as the possible area of provenience of the serpentinite used for this inlay.

The relative humidity and temperature of air were measured inside the baptistery obtaining the values of $51.7 \% \mathrm{RH}$ (relative humidity) and $27.7^{\circ} \mathrm{C}$ in the dry season (summer), and $53 \% \mathrm{RH}$ and $19^{\circ} \mathrm{C}$ in the wet season (autumn). Additional measurements, carried out in winter, gave higher relative humidity values $(71 \%)$ and lower air temperature $\left(13.2^{\circ} \mathrm{C}\right)$. Furthermore, during dry and wet seasons, some punctual surface moisture measurements were carried out along the walls at different heights, on both marble and serpentinite. The measured values do not show differences between the dry and wet seasons whereas a relevant difference has been found with the winter values and in the moisture content between the two different rocks; indeed, the values measured on marble are in the range 7.8-21 whereas on serpentinite the moisture content varies between 10 and 31.

\section{Discussion}

According to a previous study [19] and a variety of historical sources [20], the serpentinites used in the pavement of the San Giovanni baptistery mainly come from the Monte Ferrato and Impruneta quarries, located close to Florence. This rock is locally known with different names such as Verde di Prato, Nero di Prato, Marmo Nero, Paragone [19]; its texture and mineralogy have been ascribed [19] to the pseudomorphic petrological type, as defined by Wicks and Zussman in 1977 [21].

Although used in indoor conditions, the studied serpentinites display numerous forms of decay; in particular, we studied the efflorescence, clearly visible on the green inlays (Figure 5); following several authors e.g., [22,23], this form of decay, which affects the integrity and durability of the materials and their aesthetics, is mainly caused by the infiltration of water through the building walls, and successive crystallisation of the carried dissolved ions. Salt crystallisation is considered one of the most destructive processes of stones as it is responsible not only for aesthetical problems but also for extensive decay when it occurs as subefflorence [24]. This is particularly true in rocks as the studied serpentinites having relatively high porosity. The growth of salts causes stress inside the stone with a consequent additional form of decay. In the case of the studied serpentinites, we can hypothesize an important role of salts in determining the observed loss of material, discolouration, and fractures. However, as there are several factors responsible for the degradation of the pavement, it is very difficult to understand what the contribution is of each one.

The obtained analytical results indicate a combination of several factors in the origin of the different salts found in the serpentinite efflorescence. In particular, as regards the spatial distribution of salts, we observed that the less soluble sulphates have been found in the lower areas (floor) whereas the more soluble ones moved higher and crystallised on the wall. The degradation processes of stones strongly depend on the presence of water, temperature, and relative humidity [2]; water flow, between stones and the atmosphere or the subsoil, is one of the main driving factors in the degradation processes of historical buildings. For this reason, it is essential to record the main thermo-hygrometric parameters (air temperature, relative and specific humidity, dew point) and their spatial distribution to monitor their variability, localize the rising of water from the subsoil, identify the causes of these variations. 
In the San Giovanni baptistery, the temperature often undergoes daily and seasonal changes, the relative humidity is always high (water rising from the subsoil is visible in some areas of the floor, see Figure 7), testifying to inappropriate conservative microclimate conditions.

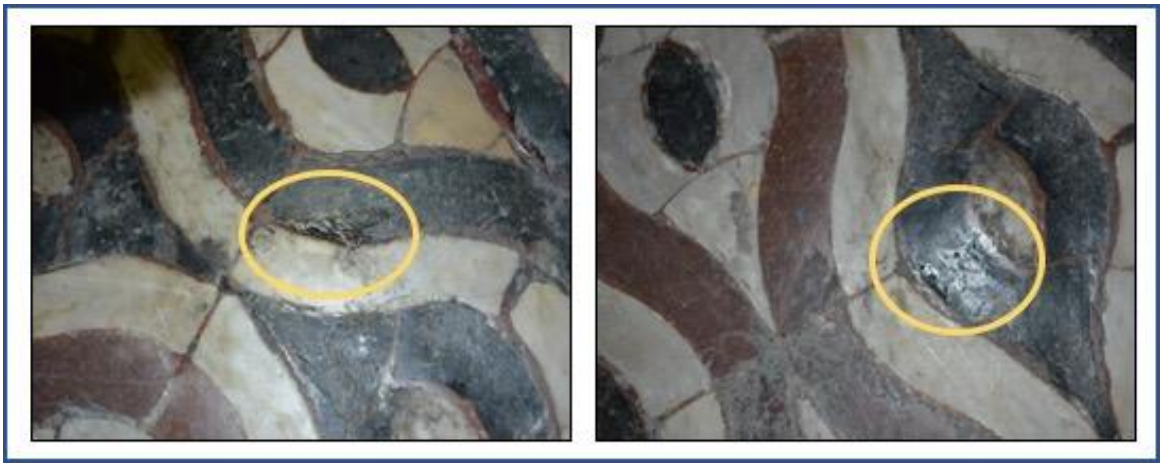

Figure 7. Detail of the baptistery pavement showing the water rising from the subsoil (yellow circles).

In addition, it is necessary to point out that the San Giovanni baptistery is located in an urban environment where the external pollutants (until 2009, car circulation was allowed very close to the baptistery) play an important role; they can penetrate inside the baptistery through the doors, causing an indoor-outdoor exchange of air, and visitors (we have to recall that the main entrance remains open yearly for thousands of hours and thousands of tourists visit the baptistery every year). Furthermore, the baptistery lies very close to, and possibly partially over, a burial ground (Figure 8a) with a consequent contribution of organic matter to the degradation processes of the floor materials through the water flow [23].

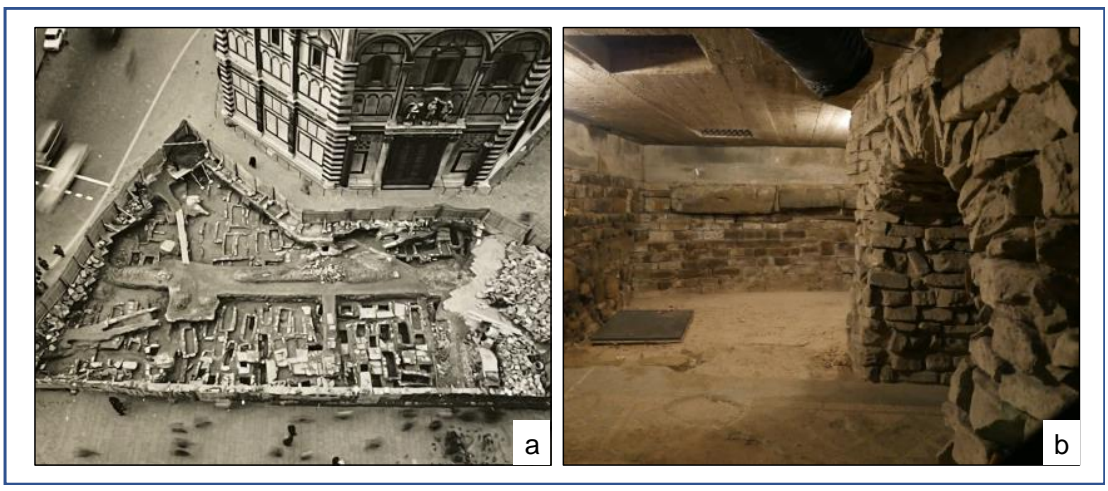

Figure 8. (a) The burial ground revealed during the excavations of 1971-1972 in Piazza del Duomo (Firenze, SABAP Fi-Pt-Po. Courtesy of the Ministry of Cultural Heritage and Activities); (b) Excavations under the SW sector of the baptistery. The modern concrete at the roof is clearly visible.

In the case of the studied floor efflorescence, the compositional analyses revealed the presence of thenardite, trona, and gypsum. The presence of thenardite, observed in four samples (EF1-3, EF11) indicates the occurrence of sulfating processes, possibly occurring within the cement or cementitious mortar [24]. Indeed, this sodium sulfate was often found in restoration mortars, manufactured with Portland cement (PC), containing a high percentage of sodium oxide $\left(\mathrm{Na}_{2} \mathrm{O}\right)$ and gypsum as additive. Due to its high solubility in water, thenardite undergoes cycles of dissolution and crystallization, according to variations in humidity and temperature. For this reason, it is, generally, the most abundant phase present in the efflorescence [22,24,25]. 
The samples EF3, EF8, EF9, EF11 contain trona which is a quite soluble, hydrated sodium carbonate that can crystallize during the setting of cement (PC) or cementitious mortars [24].

Gypsum has been found in very small quantities only in one sample (EF6); its presence could have various origins such as atmospheric pollution, the presence of Portland cement or sulphation processes of the marble inlays.

In the efflorescence sample coming from the wall, in addition to trona, we found niter and the sodium nitrosulfate, darapskite; $\mathrm{KNO}_{3}$ is very commonly observed as an efflorescence of white crystals on damp masonry walls. This mineral, already mentioned in Sumerian (2200-2100 BC) and Egyptian (1600 BC) documents, was compared in the Bible to leprosy [26,27]. In 1560, Turriano [28] observing its presence on a wall, wrote "a wall covered with snow" to indicate the aspect of this salt. The occurrence of the potassium nitrate is conditioned by the anthropic activity and environmental pollution, particularly when cement or cementitious mortars are present $[24,25,27,29]$. In some cases, the origin of efflorescence containing niter is imputed to the contribution of the organic matter from the burial area [23]. This can be also the case of the San Giovanni baptistery. Unlike niter, darapskite is a rather rare compound; it is found as crystals, granular aggregates, platy masses or as cement in different environments. In the efflorescent salts, it forms when moisture moves through building materials. This salt, observed also in association with sulphates, nitrates, and carbonates, is generally found on cement and cementitious mortars that have undergone an attack by sulphates and pollution caused by anthropic activity [29,30].

As regards the core composition (Table 2), the XRD analyses revealed, in addition to minerals coming from the materials underlying the pavement (rocks and mortars), the presence of ettringite and gypsum in the upper core; ettringite is the mineral name for the calcium sulfoaluminate $\left[\mathrm{Ca}_{6} \mathrm{Al}_{2}\left(\mathrm{SO}_{4}\right)_{3}(\mathrm{OH})_{12} \cdot 26\left(\mathrm{H}_{2} \mathrm{O}\right)\right]$ which can form through a reaction between the tricalcium aluminate, one of the components of the clinker in Portland cement (PC), or a hydraulic binder, always burned over $1000{ }^{\circ} \mathrm{C}$, and calcium sulfates. Its formation can have positive or negative effects on the durability of the concrete. The beneficial effect consists in the formation of primary or non-destructive ettringite (Early Ettringite Formation or EEF), voluntarily caused by the addition, to the Portland cement, of gypsum which delays the setting, improve the strength development reducing drying shrinkage; on the contrary, the formation of the so-called secondary or destructive ettringite (Delayed Ettringite Formation or DEF) is accidental and unwanted; it can be due to the attack of sulfate ions present in the environment or by an aggregate of the mortar polluted with sulfates [30-33]. In our case, the presence of ettringite and gypsum suggests that they could be due to the presence of cement and cementitious mortar, used in restoration intervention in the floor, or to the cement present in the vault of the crypt (Figure 8b), which has conveyed the salts in the upper layers. Indeed, the excavations under and around the baptistery and the geo-radar measurements [14] indicated the presence of modern concrete, at the base of the baptistery floor, thus, explaining the finding of ettringite in the analysed core. As a consequence, in the case of the analysed samples, ettringite could have a secondary origin, due to the attack of sulfates coming from the polluted external environment and to the high humidity present in the baptistery.

\section{Conclusions}

Variations of temperature, high relative humidity, atmospheric pollution, the presence of modern concrete and cementitious mortars in the floor and subsoil, used as a burial area, have all contributed in a different way to the decay of the San Giovanni baptistery pavement. All the decay factors need to be considered not separately; they interact between them and with the surfaces, making it very difficult to understand the role played by the single parameter.

The obtained analytical results indicate a combination of several factors in the origin of the different salts found in the serpentinite efflorescence. The mineralogical and chemical 
data showed the presence of different types of salts such as trona, thenardite, and a very small quantity of gypsum, besides niter and, darapskite in a wall of the baptistery. In particular, as regards the spatial distribution of salts, we observed that the less soluble sulphates have been found in the lower areas (floor) whereas the more soluble ones moved higher and crystallised on the wall. Following Ordóñez et al. [34] the position of salts in the walls depends on the balance between the evaporation-condensation processes (air in contact with the wall) and the flow of ions moving in the water solutions.

Most of the salts found in the efflorescence of the San Giovanni Baptistery pavement and walls are associated with the presence of PC; indeed, geo-radar measurements [13] and the excavation under the pavement revealed the presence of recent reinforcements made of modern concrete, possibly dating back to the XX century, and of a burial ground close and, possibly, under the baptistery. The physical properties of serpentinite favour the absorption of water coming from the subsoil by capillary rise. Ions such as $\mathrm{Na}^{+}, \mathrm{K}^{+}, \mathrm{NO}^{3-}$ which can be present in soils because of the anthropic activity, move into solutions through the building masonry e.g., [23], giving origin to different salt crystals. In particular, we can hypothesize that the darapskite, in addition to that associated to cement and cementitious mortars, has origin through the decomposition of the organic matter coming from the burial ground.

Besides to the role played by the salts, other decay factors have to be considered. The variability of temperature, the high values of relative humidity, and atmospheric pollution testify for inappropriate conservative microclimate conditions inside the baptistery.

According to the data reported in a previous paper [19] and to historical sources e.g., [20], the serpentinite from the baptistery pavement mainly come from Florence surrounding areas (Monte Ferrato and Impruneta). At the moment all these quarries are closed but documents kept in the archive of the Opera del Duomo suggest that the serpentinite used for the pavement was taken in the same period. However, over the years some of the inlays may have been replaced.

The carried-out study permitted obtaining relevant data concerning the processes responsible for the decay of the baptistery pavement. The San Giovanni baptistery represents a work of art of high value and a world excellence; as for all other Cultural Heritage important buildings, it is strongly necessary to include it in the maintenance and restoring program and constantly monitor its conditions to preserve it for future generations.

Author Contributions: Conceptualization, A.P.S., C.A.G. and B.A.; methodology, A.P.S.; investigation, A.P.S., E.P. and T.S.; data curation, A.P.S., E.P. and T.S.; writing-original draft preparation, A.P.S.; writing - review and editing, A.P.S., E.P. and T.S.; supervision, C.A.G. funding acquisition, A.P.S. and B.A. All authors have read and agreed to the published version of the manuscript.

Funding: This research was funded by PeritoFabbriceriaOpera del Duomo 2018 Santo 18DST.

Data Availability Statement: Not applicable.

Acknowledgments: The authors are grateful to Opera del Duomo for giving them the opportunity to study the pavement of the San Giovanni baptistery.

Conflicts of Interest: The authors declare no conflict of interest. The funders agree to publish the results.

\section{References}

1. Pereira, D.; Marker, B. The value of original natural stone in the context of architectural heritage. Geosciences 2016, 6, 13. [CrossRef]

2. Camuffo, D. Microclimate for Cultural Heritage; Elsevier: Amsterdam, The Netherlands, 2014.

3. Siegesmund, S.; Torok, A. Building stones. In Stone in Architectures. Properties, Durability; Siegesmund, E., Snethlage, R., Eds.; Springer: Berlin/Heidelberg, Germany; New York, NY, USA; Dordrecht, The Netherlands; London, UK, 2014.

4. Toker, F. A baptistery below the baptistery of Florence. Art Bull. 1976, 58, 157-167. [CrossRef]

5. Toker, F. Archaeological Campaigns below the Florence Duomo and Baptistery, 1895-1980; Brepols: Turnhout, Belgium, 2013.

6. Degli Innocenti, P. Le Origini del bel San Giovanni. Da Tempio di Marte a Battistero di Firenze; Edizioni Cusl: Firenze, Italy, 1994.

7. Nenci, C. Gli scavi nella piazza e all'interno del Battistero e del Duomo. In S. Maria del Fiore: Rilievi, Documenti, Indagini Strumentali, Interpretazioni; Piazza, Battistero, Campanile; Rocchi Coopmans de Yoldi, G., Ed.; Il Torchio: Padova, Italy, 1996. 
8. Zangheri, L. I rivestimenti policromi del San Giovanni e il policromismo orientale. In Il Battistero di San Giovanni. Conoscenza Diagnostica, Conservazione. Atti del Convegno Internazionale. Firenze, Care of Francesco Gurrieri; Mandragora: Firenze, Italy, 2014; pp. 15-26.

9. Bernabei, M.; Bontadi, J.; Quarta, G.; Calcagnile, L.; Diodato, M. The Baptistry of Saint John in Florence: The Scientific dating of the Timber Structure of the Dome. Int. J. Archit. Herit. 2016, 10, 704-771. [CrossRef]

10. Garzonio, C.A.; Cantisani, E.; Coli, M.; Cuzman, O.; De Luca, D.; Lubritto, C.; Ricci, M.; Vettori, S.; Sibilia, E. I Materiali Costitutivi del Battistero Proc. Int. Conf. on "Il Battistero di San Giovanni, Conoscenza, Diagnostica, Conservazione; Gurrieri, F., Ed.; Mandragora: Firenze, Italy, 2014; pp. 181-191.

11. Giusti, A. Il Battistero di San Giovanni a Firenze; Panini, F.C.: Modena, Italy, 2013; p. 275.

12. Lorenzi, C. Osservazioni in Margine ad Alcune Malnote Fonti di un Passo Della Nuova Cronica di Giovanni Villani (XII iii). Lettere Italiane; Leo S. Olschki s.r.l.: Florence, Italy, 2011; Volume 63, pp. 577-585.

13. Coli, M.; Donigaglia, T.; Iandelli, N.; Ciuffreda, A.L.; Agostini, B.; Papeschi, P.; Giannino, F. Rilievi Georadar nel Sottosuolo del Battistero di San Giovanni a Firenze; AIPnD Conferenza Nazionale: Milano, Italy, 2019.

14. Antonio Paolucci (Care of) Il Battistero di San Giovanni a Firenze; Panini: Modena, Italy, 1984; p. 659.

15. Pereira, D.; Peinado, M.; Yenes, M.; Monterrubio, S.; Nespereira, J.; Blanco, J.A. Serpentinites from Cabo Ortegal (Galicia, Spain): A search for correct use as ornamental stones. Geol. Soc. Lond. Spec. Publ. 2010, 333, 81-84. [CrossRef]

16. Ismael, I.S.; Hassan, M.S. Characterization of some Egyptian serpentinites used as ornamental stones. Chin. J. Geochem. 2008, 27, 140-149. [CrossRef]

17. UNI-EN 1925. Metodi di Prova per Pietre Naturali. Determinazione del Coefficiente di Assorbimento D'acqua per Capillarità; UNI (Ente Italiano di Normazione): Milano, Italy, 2000.

18. UNI EN 13755. Metodi di Prova per Pietre Naturali-Determinazione Dell'assorbimento D'acqua a Pressione Atmosferica; UNI (Ente Italiano di Normazione): Milano, Italy, 2008.

19. Santo, A.P.; Pecchioni, E.; Garzonio, C.A. The San Giovanni Baptistery in Florence (Italy): Characterisation of the serpentinite floor. IOP Conf. Ser. Mater. Sci. Eng. 2018, 364, 012069. [CrossRef]

20. Corti, M. Il Verde di Prato: Una Risorsa Naturale e Storica dell'Area Protetta del Monteferrato, Prato; Centro di Scienze Naturali Press: Prato, Italy, 2006; p. 158.

21. Wicks, F.J.; Whittaker, E.J.W. Serpentine textures and serpentinization. Can. Miner. 1977, 15, 459-488.

22. Aguayo, T.; Clavijo, E.; Eisner, F.; Ossa-Izquierdob, C.; Campos-Vallettea, M.M. Raman spectroscopy in the diagnosis of the wall painting History of Concepcion. Chile Wiley Online Libr. 2011, 42, 2143-2148. [CrossRef]

23. D'Agostino, D.; Macchia, A.; Cataldo, R.; Campanella, L.; Campbell, A. Microclimate and Salt Crystallization in the Crypt of Less's Duomo. Int. J. Archit. Herit. 2015, 9, 200-209. [CrossRef]

24. Gomez-Laserna, O.; Olazabal, M.A.; Morillas, H.; Prieto-Taboada, N.; Martinez-Arkarazo, I.; Arana, G.; Madariaga, J.M. In-situ spectroscopic assessment of the conservation state of building materials from a Palace house affected by infiltration water. $J$. Raman Spectrosc. 2013, 44, 1277-1284. [CrossRef]

25. Morillas, H.; Maguregui, M.; Trebolazabala, J.; Madariaga, J.M. Nature and origin of white efflorescence on bricks, artificial stones, and joint mortars of modern houses evaluated by portable Raman spectroscopy and laboratotory analyses. Spectrochim. Acta Part A Mol. Biomol. Spectrosc. 2015, 136, 1195-1203. [CrossRef] [PubMed]

26. Thorwald, J. Science and Secrets of Early Medicine; Winston, R.; Winston, C., Translators; Harcourt, Brace \& World, Inc.: New York, NY, USA, 1962.

27. Barnum, D.W. Some history of nitrates. J. Chem. Educ. 2003, 80, 1393-1396. [CrossRef]

28. Turriano, J. Book of Machines; "XXI Libros de Maquinas" Madrid B.N. MS 3372-3376; Keller, A.G., Translator; American Chemical Society: Washington, DC, USA, 2003; Volume 80, p. 1560.

29. Laviano, R. I materiali lapidei pugliesi: Loro utilizzo ed alterazione nei Beni Culturali. In Rendiconti della Accademia Nazionale delle Scienze detta dei XL. Memorie di Scienze Fisiche e Naturali: 124 (2006), vol XXX, p. II; Ballio, A., Ed.; Accademia Nazionale delle Scienze detta dei XL: Roma, Italy, 2007; pp. 205-248.

30. Holtkamp, M.; Heijnen, W. The mineral darapskite in the efflorescence on two dutch churches. Stud. Conserv. 1991, 36, 175-178.

31. Pecchioni, E.; Fratini, F.; Cantisani, E. Atlas of the Ancient Mortars in Thin Section under Optical Microscope, 2nd ed.; Nardini: Firenze, Italy, 2020.

32. Pecchioni, E.; Fratini, F.; Cantisani, E. Le Malte Antiche e Moderne tra Tradizione e Innovazione, 2nd ed.; Pàtron: Bologna, Italy, 2018.

33. Arizzi, A.; Cultrone, G. Mortars and plasters-How to characterise hydraulic mortars. Archaeol. Anthropol. Sci. 2021, 13, 144. [CrossRef]

34. Ordóñez, S.; La Iglesia, Á.; Louis, M.; García del Cura, M.Á. Mineralogical evolution of salt over nine years, after removal of efflorescence and saline crusts from Elche's Old Bridge (Spain). Constr. Build. Mater. 2016, 112, 343-354. [CrossRef] 